\title{
Un comedor para Yolanda
}

\author{
Fernán Odio Fonseca
}

L a gente de la montaña estaba disgregada. Los más pobres al fondo y los turistas por delante. Era obvio que la camioneta ya no volvería al pueblo de Quiché o Acatenango. Las colillas de los cigarros volaban por las ventanillas dejando un rastro de tabaco con leña quemada: el olor de una cultura.

Al llegar a las Pilas de la Merced, Yolanda se puso a lavar la ropa que traía en su canasto. Su espalda le dolía. Llegó a confundir la tela con la madera, y el olor del jabón con el aceite de maíz. Los perros se le acercaban y las pulgas caían como chispas de fuego. El huipil que traía estaba estampado con formas de rosas y diferentes figuras, que, a ojos de ciudadanos o curiosos, podían ser algo más que mensajes astrales. Una vez tendida la ropa, el canasto se ocupó de lo demás, y la humedad del mediodía se encargó de picar la piel de los caminantes.

La mujer pasó por el Arco de Santa Catalina. La arquitectura tapaba el volcán de agua. Las nubes tocaban la punta de la montaña que una vez había inundado el pueblo para castigar a los hombres que desafiaron al dios del sol. El reloj de la estructura parecía estar hecho de hielo.

Yolanda llegó a la puerta de una casa amarilla. Las ventanas estaban abarrotadas con hileras de tubos de hierro y el marco tenía vidrio. Su reflejo no era muy diferente de aquel que le daba el río.

Tocó tres veces la puerta. Estuvo a punto de volverse, pero una mano la tomó por sorpresa, y un rostro oscuro le hablaba en una lengua extraña mientras se acomodaba la trenza del pelo.

El Kaqchikel entretuvo a Yolanda por un tiempo. El español no lo dominaba muy bien, pero menos el inglés, un idioma solo para aquellos que afianzaran con el extranjero. Su hermana, Nikte, le mostró la casa. El sonido de una lora se oía a lo lejos y el lavabo estaba encendido. Yolanda vio el agua caer en una pila de platos sucios. Tuvo curiosidad de su hermana y pensó en la fosa de la montaña.

La noche se hizo muy espesa en sonidos, y la mujer de Quiché siempre escuchó todo lo que se movía en la oscuridad: el ulular del Tecolote, el mosquito en la sábana y el aleteo del murciélago en el tejado.

Al llegar la mañana, no faltaron los sonidos domésticos de las tazas de café o el cacareo de la gallina. Un olor a maíz se coló por las rendijas de madera, y la mantequilla empezó a quemarse en el asador. 
Llegaron los ruidos de la calle con sus vehículos y cascos de caballo. Las puertas del comedor estaban abiertas y Nikte preparaba tortillas y chicharrones. Después de que la carne vacuna estuviera en su punto, las gotas de limón se evaporaron en el comal.

Yolanda dio a Nikte una pulsera de tela. Era un regalo. Las palabras no se ocuparon para aquella mañana, ya que entre familia los gestos se resumían en miradas cargadas de recuerdos. El comal y las ollas dieron la señal de la siguiente oleada de comida y los pueblerinos se acercaron casi todos con sus huipiles y canastos. El aire se llenó de una única lengua, y Yolanda cargó su mañana de memorias. 